\title{
ARTYKUŁY
}

Klio. Czasopismo poświęcone dziejom Polski i powszechnym

PL ISSN 1643-8191, t. 28 (1)/2014, s. 63-83

(1) $\odot$

DOI: http://dx.doi.org/10.12775/KLIO.2014.004

KAMIL ŚMIECHOWSKI

(Łódź)

\section{Strategie władz carskich wobec tódzkiej prasy codziennej do 1914 roku}

工 ódź była jednym z pierwszych miast Królestwa Polskiego, które doczena gazeta wydawana w mieście, którą były „Łódzkie Ogłoszenia - Łodzier Anzeiger” Johanna Petersilgego, przekształcona w 1865 roku w pełnoprawny niemieckojęzyczny dziennik „Lodzer Zeitung”. W 1884 roku, po pewnych eksperymentach polegających na próbach publikowania polskich kronik czy dodatków na łamach wspomnianego dziennika, zaczął się ukazywać pierwszy regularny dziennik polski w mieście, tj. „Dziennik Łódzki”, redagowany przez Henryka Elzenberga. Przetrwał on do 1892 roku. Na przełomie XIX i XX wieku do prasy polskiej i niemieckiej rozwijającej się w „polskim Manchesterze" dołączyły również periodyki żydowskie.

${ }^{1}$ Szczegółowe informacje na temat prasy wydawanej w Łodzi na przełomie XIX i XX wieku zawierają następujące opracowania: W. Kaszubina, Czasopiśmiennictwo tódzkie w latach 1863-1914. Próba zarysu, „Rocznik Biblioteki Narodowej” 1970, t. 6, s. 207-242; J. Jaworska, Prasa, [w:] Eódź. Dzieje miasta, red. R. Rosin, t. 1: Do roku 1918, red. B. Baranowski, J. Fijałek, wyd. 2, Warszawa-Łódź 1988, s. 546-555. O poszczegól- 
Łódź była przykładem ośrodka, w którym władze i cenzura carska odcisnęły szczególne piętno na dziejach miejscowej prasy polskojęzycznej: kolejne organy - „Dziennik Łódzki” (1884-1892), „Goniec Łódzki” (18981906) i „Kurier Łódzki” (1906-1911) ulegały likwidacji w wyniku decyzji o charakterze politycznym. Represji nie uniknął także „Rozwój”, wydawany przez Wiktora Czajewskiego w latach 1897-1915. O cenzurze polskiej w Łodzi a także o stosunku władz do prasy wydawanej w tym mieście napisano już sporo. Prym w tych badaniach wiodła Janina Jaworska, która na przełomie lat sześćdziesiątych i siedemdziesiątych XX wieku opublikowała dwa obszerne artykuły źródłowe, poświęcone dziejom miejscowej cenzu$\mathrm{ry}^{2}$. Pierwszy z nich stanowił omówienie szczegółowych relacji pomiędzy cenzurą a "Gońcem Łódzkim”; drugi - próbę syntetycznego ujęcia dziejów tej instytucji, w którym nacisk położono na kwestie organizacyjne i personalne. $\mathrm{O}$ relacjach z cenzurą, a także ogólnym stosunku władz do prasy, pisali autorzy szczegółowych monografii łódzkich dzienników - „Dziennika Łódzkiego” (Zygmunt Gostkowski) ${ }^{3}$ i „Rozwoju” (Jan Chańko) ${ }^{4}$. Co istotne, ten obszerny, choć niepełny jeszcze - nieuwzględniający na przykład w ogóle stosunku władz do prasy niemieckiej i żydowskiej - dorobek historiograficzny, powstał w całości przed kilkudziesięcioma laty, w okresie PRL. Od tamtej pory w naukach historycznych przybyło wiele cennych obserwacji teoretycznych i interpretacji carskiego systemu prasowego, sformułowanych już w nowych realiach uprawiania nauki, uwolnionych od - nomen

nych tytułach: eadem, „Goniec Łódzki” (1898-1906) wobec rosyjskiej cenzury, „Roczniki Biblioteczne” 1966, t. 10, s. 363-392; J. Chańko, Gazeta „Rozwój” (1897-1915). Studium źródtoznawcze, Łódź 1982 [wydano drukiem tylko tom I opracowania]. O prasie innych narodowości: L. Olejnik, $Z$ dziejów prasy żydowskiej $w$ Łodzi w latach 1904-1918, [w:] Dzieje Żydów w Łodzi 1820-1944, red. S. Liszewski, W. Puś, Łódź 1991, s. 140-157; M. Kucner, Prasa niemiecka w Łodzi 1863-1939, [w:] Rola Niemców w Łodzi do roku 1945, red. K. A. Kuczyński, B. Ratecka, Łódź 1997, s. 209-235. Zob. też: W. Kaszubina, Bibliografia prasy tódzkiej 1863-1944, Warszawa 1967.

2 J. Jaworska, Goniec..., passim; eadem, Cenzura carska w Łodzi przed pierwsza wojna światowa, „Roczniki Biblioteczne” 1973, z. 1-2, s. 121-153.

3 Z. Gostkowski, „Dziennik Eódzki” 1884-1892. Studium nad powstawaniem polskiej opinii publicznej w wielonarodowym mieście fabrycznym, Łódź 1960, s. 54-76.

“ J. Chańko, Gazeta „Rozwój” (1897-1915). Studium źródtoznawcze, t. 2, Łódź 1980 [mps w Pracowni Dydaktyki i Technologii Informacyjnej UŁ], s. 260-272. 
omen - ograniczeń wolności słowa ${ }^{5}$. Znacząco zwiększyła się też nasza wiedza na temat Łodzi przełomu XIX i XX wieku, ze szczególnym uwzględnieniem panujących w mieście stosunków wyznaniowo-narodowościowych oraz społecznych. Dorobek ten warto skonfrontować z wiedzą o cenzurze carskiej w Łodzi a także z zachowanym materiałem źródłowym ${ }^{6}$ w celu wypracowania nowego, uwzględniającego aktualny stan badań i refleksji teoretycznych, spojrzenia na problem wzajemnych relacji władz carskich i prasy w Łodzi do 1914 roku.

Jednym z najbardziej intrygujących wyzwań wydaje się postawienie pytania, czy stosunek władz zaborczych do łódzkiej prasy miał - jak chciałaby to ujmować klasyczna historiografia - charakter jedynie kontrolno-represyjny, nastawiony na karanie wydawców i redaktorów za kolejne „wykroczenia”, czy też może układ wzajemnych relacji pomiędzy władzą a prasą był o wiele bardziej złożony. Henryk Bałabuch, autor studium o uwarunkowaniach funkcjonowania prasy prowincjonalnej Królestwa Polskiego po 1865 roku, pisze na przykład, że

ważny jest [...] kontekst funkcjonowania cenzury. Czy można działania cenzury [...] sprowadzać jedynie do szykan zaborcy o antypolskim podłożu, jeżeli w tym samym okresie prasa rosyjska represjonowana była w znacznie poważniejszym stopniu, tyle, że punkt wyjścia był inny??

${ }^{5}$ M. Tobera, Cenzura czasopism w Królestwie Polskim na przetomie XIX i XX wieku, „Przegląd Historyczny” 1989, t. 80, s. 41-67; Pismiennictwo - systemy kontroli-obiegi alternatywne, red. J. Kostecki, A. Brodzka, Warszawa 1992; W. Caban, Cenzura w Królestwie Polskim w latach 1815-1915, [w:] Granice wolności stowa. Materiaty konferencji naukowej. Kielce 4-5 maja 1995 r., red. G. Miernik, Kielce-Warszawa 1995; У мызсли стол на часах... Цензоры России и чензура, реА. Г. В. Жиркова, Sankt-Petersburg 2000; H. Bałabuch, Nie tylko cenzura. Prasa prowincjonalna Królestwa Polskiego $w$ rosyjskim systemie prasowym 1865-1915, Lublin 2001, s. 29-119; Prasa Królestwa Polskiego w opinii wtadz cenzury rosyjskiej (1901-1914), oprac. J. Kostecki, M. Tobera, Warszawa 2013; Цензоры Российской Империи, конеи ХVIII - начало ХХ века: биобиблиографический справочник, Sankt-Petersburg 2013.

${ }^{6}$ Akta łódzkiej cenzury znajdują się przede wszystkim w Archiwum Państwowym w Łodzi, w zespole Kancelaria Gubernatora Piotrkowskiego [dalej: APŁ, KGP]. Obejmują kilkanaście tomów akt $\mathrm{z}$ lat 1897-1914.

${ }^{7}$ H. Bałabuch, Nie tylko..., s. 31 . 
Ten sam autor, dociekając, dlaczego po upadku powstania styczniowego władze nie tylko nie doprowadziły do faktycznej likwidacji polskiej prasy, ale wręcz - mimo szykan i represji - zezwoliły na jej olbrzymi rozwój, przeanalizowawszy różne możliwe wyjaśnienia tego fenomenu, doszedł do wniosku, że „racjonalne wydaje się tłumaczenie postawy władz chęcią podporządkowania sobie prasy, włączenia jej w służbę interesów państwa”8.

Powyższym tezom w sukurs przychodzi Zbigniew Anculewicz, autor pomnikowego dzieła o „Kurierze Warszawskim”, który stawia wręcz hipotezę, że urzędnicy Warszawskiego Komitetu Cenzury w stosunkach z redakcją tego największego dziennika Królestwa, odgrywali rolę inspirująca, tak modyfikując na bieżąco swą politykę względem pisma, by produkt finalny, którym były treści płynące z kart „Kuriera”, w największym możliwym stopniu odpowiadał bieżącym interesom władz zaborczych?

Oczywiście polska prasa nie spełniała na ogół tych nadziei. Czy jednak rzeczywiście władzom z rzadka tylko udawało się skierować jej uwagę na „właściwe” ze swojego punktu widzenia tory? Czy - w kontekście łódzkim - czerwony ołówek cenzora pozostawał narzędziem w rękach kapryśnego urzędnika niskiego stopnia, czy też był raczej rozmyślnie używanym narzędziem, służącym do realizacji polityki, sformułowanej na podstawie określonego katalogu pryncypiów?

Warto w tym miejscu zauważyć, że - jak pisze chociażby Andrzej Szwarc w odniesieniu do „Dziennika Łódzkiego” - casus łódzkich dzienników „nie był typowy, bo i Łódź odbiegała od Lublina czy Kielc” ${ }^{10}$. W celu zilustrowania pewnych założeń polityki władz w stosunku do prasy łódzkiej w literaturze przedmiotu najczęściej odwoływano się do pisma, które 4 grudnia 1898 roku wystosował do generat-gubernatora warszawskiego gubernator piotrkowski Konstantin Miller. Gubernator donosił w nim Aleksandrowi Imeretyńskiemu o „jawnym wyuzdaniu” (jawnoj razdustannosti) polskiej prasy w Łodzi, reprezentowanej wówczas przez „Rozwój”

8 Ibidem, s. 38.

9 Z. Anculewicz, Świat i ziemie polskie w oczach redaktorów i wspótpracowników „Kuriera Warszawskiego" 1898-1915, Warszawa 2002, s. 30.

10 A. Szwarc, Inteligencja warszawska i prowincjonalna $w$ świetle wtasnych opinii z lat popowstaniowych (próba sondażu), [w:] Inteligencja polska XIX i XX w., red. R. CzepulisRastenis, Warszawa 1983, s. 206. 
i "Gońca Łódzkiego", których działalność miała zagrażać porządkowi publicznemu w mieście ${ }^{11}$. Zdaniem K. Millera punktem odniesienia dla dokonania oceny stosunków, były kwestie narodowościowe. Łódź, jak wiadomo, rozwinęła się w pierwszej połowie XIX wieku głównie dzięki napływowi rzemieślników pochodzenia niemieckiego. Choć pod koniec stulecia Polacy stanowili już niemal połowę mieszkańców miasta a olbrzymią dynamikę wzrostu notowała też ludność żydowska ${ }^{12}$, wciąż jeszcze najstarsza i najbardziej wpływowa część miejscowych elit przemysłowych, a także większość kadry technicznej rekrutowała się z rodzin byłych niemieckich kolonistów ${ }^{13}$. Taki stan rzeczy nie mógł zyskiwać aprobaty w oczach inteligencji Królestwa, krytykującej na łamach warszawskiej prasy panujące w Łodzi realia narodowościowo-własnościowe ${ }^{14}$, ani jej miejscowych przedstawicieli, którzy począwszy od lat osiemdziesiątych ujawnili własne aspiracje kulturalne, pragnąc - jak to ocenił K. Miller - spolszczyć (opoliaczit) miasto. Spostrzeżenia te stanowiły dla gubernatora piotrkowskiego punkt wyjścia do sformułowania naczelnej zasady polityki rosyjskiej w stosunku do procesów narodowościowych i społecznych zachodzących w „polskim Manchesterze":

ze słowiańskiego punktu widzenia należałoby życzyć sobie postępu takich dążeń Polaków, lecz w wylącznych interesach Rosji w kraju tutejszym, postępy takie, są w mojej krańcowej ocenie niepożądane ${ }^{15}$.

11 Pismo Gubernatora Piotrkowskiego Konstantego Millera do Generał-Gubernatora Warszawskiego z 4 grudnia 1898, APŁ, KGP, 1129, k. 236-241.

12 Według spisu powszechnego z 1897 r. Łódź zamieszkiwało 46,4\% Polaków, 29,4\% Żydów oraz 21,4\% Niemców. Po 18 latach, w 1915 r., proporcje te przedstawiały się następująco: Polacy 51,4\%, Żydzi 36,4\%, Niemcy 11,5\%. Zob.: J. Janczak, Ludność Łodzi przemystowej 1820-1914, Łódź 1982, s. 115-136.

13 S. Pytlas, Łódzka burżuazja przemystowa w l. 1864-1914, Łódź 1994, s. 43, 46-48, 64.

${ }_{14}$ Zob.: K. Śmiechowski, Z perspektywy stolicy. Łódź w oczach warszawskich tygodników spoteczno-kulturalnych 1881-1905, Łódź 2012, s. 54-76, 94-114.

15 APŁ, KGP, 1129, k. 237. 
Takie stanowisko władz carskich nie było niczym nowym. Już rok wcześniej generał-gubernator warszawski, Paweł Szuwałow, w skierowanym do cara raporcie expressis verbis stwierdzał:

Dla nas sukcesy te [tj. rozwój wielkiego przemysłu w Królestwie Polskim - K. Ś.] ważne są nie tylko z tych względów, że w nich ujawnia się wzrost gospodarczy tutejszej ludności, ale także dlatego, że przynoszą najlepszą odpowiedź na te polskie napaści na rząd rosyjski, w których próbuje się przekonać cały świat, że pomyślność kraju nie wiąże się z systemem samowładztwa rosyjskich carów, ale że należy jej podobno szukać w sąsiedniej autonomii Galicji.

[...] Co się tyczy charakteru miejscowego stanu przemysłowego i jego stosunku do rządu, to uwaga najbogatszych jego przedstawicieli skupiona jest na rozwoju własnego dobrobytu materialnego, a przy dominacji tak samolubnych skłonności polsko-narodowe idee mogą zajmować w ich umysłach ostatnie miejsce, tym bardziej że wśród najbardziej znamienitych przedstawicieli miejscowego stanu przemysłowego jest sporo obcokrajowców, którzy ściągnęli tu znaczne kapitały, i którym oczywiście obce są tęsknoty za utraconą przez Polskę niepodległością ${ }^{16}$.

Nie ulega wątpliwości, że paradygmat ów sformułowany został już w latach osiemdziesiątych. Właśnie wówczas doszło do ostrej napaści rosyjskich kół przemysłowych, reprezentowanych przez Siergieja Szarapowa, na rozwijający się przemysł Królestwa Polskiego, który stanowił dlań zbyt silną konkurencję ${ }^{17}$. Aspekt narodowościowy, wykorzystywany w sposób ksenofobiczny, był istotnym - o ile nie najistotniejszym - elementem krytyki łódzkiego przemysłu ze strony rosyjskich kół przemysłowych oraz tamtejszej prasy ${ }^{18}$. Nie można zatem nie dostrzegać, że atak S. Szarapowa

${ }^{16}$ Sprawozdanie warszawskiego generata-gubernatora, generata piechoty hrabiego Szuwatowa o sytuacji Królestwa Polskiego, [w:] Warszawscy generatowie-gubernatorzy o sytuacji spoteczno-politycznej Królestwa Polskiego. Raporty Albiedynskiego i Szuwatowa z lat 1881 i 1896, oprac. S. Wiecha, Kielce 2007, s. 202-203.

${ }_{17}$ Zob.: O. Wasińska, Walka konkurencyjna przemystu tekstylnego okreggu tódzkiego $z$ regionem moskiewskim $w$ latach 1885-1893, „Studia z historii społeczno-gospodarczej XIX i XX wieku” 2004, t. 2, s. 152-166.

${ }^{18}$ Ibidem, s. 154, 164-165. Zob. też: A. Jezierski, Problemy wzrostu gospodarczego Polski w XIX wieku, [w:] Polska XIX wieku. Państwo spoteczeństwo kultura, red. S. Kieniewicz, Warszawa 1982, s. 112-114. 
w sposób niepozostawiający żadnych wątpliwości zbiegł się z podjęciem przez czołowe opiniotwórcze tygodniki warszawskie, w tym „Prawdę” i „Przegląd Tygodniowy”, krytyki nadmiernego znaczenia pierwiastka niemieckiego w przemyśle włókienniczym okręgu łódzkiego ${ }^{19}$. Stołeczni publicyści, domagając się szerszego otwarcia podwojów łódzkich fabryk przed polską inteligencją techniczną oraz zarzucając łódzkiej burżuazji zbyt słabe angażowanie się w inicjatywy o charakterze ogólnokrajowym, występowali w obronie zarówno wymiernych polskich interesów ekonomicznych, jak i narodowościowych, i to w skali całego Królestwa. W tej sytuacji drugorzędną sprawą stawał się fakt, że, przystępując do działania, połknęli oni jedynie haczyk rzucony im przez przemysłowe kręgi rosyjskie zainteresowane ochroną własnego przemysłu przed wyniszczającą „konkurencją wewnętrzną" ze strony Łodzi czy Sosnowca ${ }^{20}$.

Głównym przegranym tej sytuacji z całą pewnością pozostawał „Dziennik Łódzki”, pismo o orientacji wyraźnie pozytywistycznej, założone w 1884 roku przez Henryka Elzenberga, absolwenta Szkoły Głównej, byłego współpracownika warszawskiej „Niwy” oraz „Opiekuna Domowego”. Program H. Elzenberga, zakładający asymilację do polskości łódzkich kręgów przemysłowych, nie wpisywał się ani w strategię władz, ani w uczucia opinii publicznej Królestwa, upatrującej fenomen Łodzi raczej przez pryzmat własnego nacjonalizmu ekonomicznego niż szukającej sposobów do wypracowania zdrowego kompromisu z łódzką burżuazją czy środowiskiem niemieckim „polskiego Manchesteru”21 . „Dziennik” przez cały okres ukazywania musiał się borykać z obustronną krytyką, tak ze strony pracowników Warszawskiego Komitetu Cenzury, dobrze - jak się zdaje - rozumiejącego uwarunkowania zawarte później w cytowanych powyżej raportach gubernatorów, który to zajmował się jego cenzurowaniem, co, choćby ze względu na odległość obu miast, nastręczało redakcji wiele trudności - jak i prasy warszawskiej. Za ambicje reprezentowania interesów łódzkiego przemysłu a także związki finansowe i personalne z największymi łódzkimi zakładami Karola Scheiblera, pismo H. Elzenberga od początku było ostro krytykowa-

\footnotetext{
${ }^{19}$ K. Śmiechowski, $Z$ perspektywy..., s. 55 i następne.

${ }^{20}$ Ibidem.

${ }^{21}$ Zob.: Z. Gostkowski, Dziennik..., s. 141-156.
} 
ne przez „Prawdę” Aleksandra Świętochowskiego ${ }^{22}$. Szczególnie silne ataki zarówno na „Dziennik” i H. Elzenberga, jak i na stosunki narodowościowe panujące w mieście, sygnowane były piórem Antoniego Wiśniewskiego ${ }^{23}$, byłego sekretarza redakcji łódzkiego pisma, później współpracownika warszawskiego „Głosu”, zdemaskowanego zresztą później z powodu współpracy z Ochraną ${ }^{24}$.

Koleje losu łódzkiego „Dziennika” wskazują na elementy taktyki, którą stosowały władze w odniesieniu do środowisk zamieszkujących w wielonarodowej Łodzi. Marian Płachecki pisał, że

\begin{abstract}
instytucjonalizowanie władzy carskiej w Królestwie polegało również na izolowaniu, rozpraszaniu i degradowaniu miejscowej inteligencji. [...] Strategia izolowania elit była o tyle skuteczna, o ile prowadziła do wtórnej askryptiwizacji pozycji społecznych. Poszczególnych członków społeczeństwa niejako zamrażała w ich grupach statusowych, utrudniając im opuszczenie owych grup, a już zwłaszcza przechodzenie do grup wyższych ${ }^{25}$.
\end{abstract}

W kontekście łódzkim polegała ona w pierwszym rzędzie na powstrzymywaniu haseł asymilacyjnych, zmierzających do włączenia miejscowego mieszczaństwa obcego pochodzenia w nurt polskiego życia społecznego, przy jednoczesnym zezwalaniu na stałe podważanie przez prasę warszawską zarówno polskości samej Łodzi, jak i intencji działającego w niej środowiska polskiej inteligencji. Znamienne, że, mimo iż już w 1886 roku Warszawski Komitet Cenzury uznał „wzbudzanie nienawiści do niemczyzny w Królestwie” za szkodliwe ${ }^{26}$, to, gdy w 1892 roku doszło do tzw.

22 W. Piotrowski, Łódź w „Prawdzie” Aleksandra Świętochowskiego (1881-1886), „Przegląd Nauk Historycznych i Społecznych” 1954, t. 4, s. 236-267.

${ }_{23}$ Zob.: A. Wiśniewski, Wobronie wtasnej, „Głos” 1889, nr 5, s. 58; idem, Przeglad spoteczny, „Głos” 1889, nr 19, s. 247; idem, Eódź i todzianie, „Przegląd Tygodniowy” 1889, cz. 1, nr 6, s. 75-76; cz. II, nr 9, s. 122-123; cz. 3, nr 28, s. 362-363; cz. IV, nr 37, s. 336; cz. V, nr 47, s. 592.

${ }^{24}$ H. Karwacka, Artur Glisczyński pieśniarz fabrycznej Łodzi, Łódź 1975, s. 30.

${ }_{25}$ M. Płachecki, Makrospoteczna sytuacja komunikowania $w$ dobie niewoli (Królestwo Polskie 1864-1885), [w:] Piśmiennictwo..., s. 244-245.

26 P. Szreter, Cenzura rosyjska $w$ Warszawie między powstaniem styczniowym a rewolucja 1905-1907. Strategie dziatania, [w:] ibidem, s. 256. 
buntu łódzkiego, czyli wystąpienia robotników przeciwko uciskowi ze strony obcych majstrów i przełożonych, nie rozumiejących często nawet języka polskiego ${ }^{27}$, w ramach szerokich represji za to wydarzenie zamknięto właśnie „Dziennik Łódzki” ${ }^{28}$, jednocześnie nie ograniczając zbytnio prasie warszawskiej możliwości pisania o kwestii narodowościowej w Łodzi. Na łamach tej ostatniej nie kryto zresztą radości z powodu podjętej wówczas decyzji o przeprowadzeniu wśród kadry technicznej łódzkich zakładów egzaminów ze znajomości języków polskiego i rosyjskiego i wydaleniu tych z jej przedstawicieli, którzy nie zdołają ich zdać. Zamknięcie łódzkiego „Dziennika” przyjmowano natomiast z mieszanymi uczuciami, z reguły zdobywając się jednak na podkreślanie niezwykle - jak na warunki prowincjonalne - wysokiego poziomu tego pisma ${ }^{29}$.

Wydarzenia 1892 roku każą nam na nowo spojrzeć na dwie opinie często powtarzane w historiografii, których wiarygodność wypada dziś zaopiniować negatywnie. Pierwsza z nich mówi o germanofilskim nastawieniu władz rosyjskich na terenie Łodzi, przejawiającym się w zwalczaniu rozwoju kultury polskiej przy jednoczesnym popieraniu niemieckiej ${ }^{30}$. Niemcy łódzcy oraz zamieszkujący region istotnie stanowili, z punktu widzenia władz, pierwiastek odznaczający się sporą przewidywalnością i ugodową postawą. Jako typowa diaspora uzależniona ekonomicznie od stabilizacji kraju, w którym się wzbogacili, siłą rzeczy przyjmowali oni raczej postawę apolityczną, cechując się przy tym niemałą karnością. Ostatnie dekady XIX oraz pierwsze lata XX wieku nie były jednak dla tego środowiska łatwe. Zaznaczyć trzeba, że z jednej strony musiało ono przyjmować coraz częstsze ataki ze strony rosyjskiego nacjonalizmu, ciągle podnoszącego larum z powodu tak wysokiego odsetka ludności niemieckiej w całej

${ }^{27}$ Zob.: „Bunt tódzki” 1892 roku. Studia z dziejów wielkiego konfliktu spotecznego, red. P. Samuś, Łódź 1993, passim.

${ }^{28}$ Formalną przyczyną zamknięcia pisma było umieszczenie w gazecie artykułu zakwestionowanego przez WKC na skutek błędnego telegrafu ze stolicy. W ramach represji najpierw podjęto wówczas decyzję o zawieszeniu pisma na 8 miesięcy, następnie zaś o odebraniu koncesji na jego druk. J. Walicki, „Dziennik Łódzki”: Nasze 115-lecie, Łódź 1999, s. 39 .

${ }^{29}$ K. Śmiechowski, $Z$ perspektywy..., s. 111-112.

30 Zob.: Z. Gostkowski, „Dziennik..., s. 61-63. 
guberni piotrkowskiej w obliczu zwiększającego się zagrożenia ze strony samych Niemiec. Ponadto stan posiadania Niemców w Królestwie i Łodzi był stale kwestionowany przez środowisko polskie. Sytuacja taka pchała zatem społeczność niemiecką w objęcia władz zaborczych, zmuszając ją do wykonywania coraz liczniejszych gestów wiernopoddańczych, często nie do końca szczerych ${ }^{31}$.

Musiało to wzbudzać dyskomfort wśród przedstawicieli niemieckiej burżuazji łódzkiej, osłabiało bowiem znacząco jej pozycję w walce konkurencyjnej z przemysłem rosyjskim. Jeśli zatem Niemcy łódzcy istotnie znajdowali się pod pewną ochroną ze strony administracji carskiej, to nie była to w żadnej mierze ochrona bezinteresowna. Najlepiej o tym świadczy bardzo ostra polemika między „Dziennikiem” a „Lodzer Zeitung” z 1886 roku. Polska gazeta, wpisując się w ogólny ton prasy Królestwa, zaczęła traktować niemieckie pismo jako przeszkodę w realizacji jej programu polonizacji miasta, zarzucając jej tendencje separatystyczne. W często cytowanej replice na te ataki, redakcja popularnej „Lodzerki” pisała:
Z dziecinną naiwnością oświadcza „Dziennik Łódzki”, że uważa nasze pismo za szkodliwe, a istnienie takowego za rzecz wywołującą nieza- dowolenie w jego kraju. Szanowna redakcjo „Dziennika Łódzkiego”. Co też rozumiesz pod swoim krajem, Lwów czy też może Poznań? Bo chyba nie naszą ojczyznę. W Rosji, tym potężnym państwie, którego synami jesteśmy, którego synami byli nasi ojcowie i przodkowie, a któ- remu to państwu z niezmierną miłością i wiernością oddani jesteśmy... wszędzie tam jak daleko orzeł dwugłowy rozpościera swe potężne skrzy- dła ponad własnością swoją, jesteśmy i czujemy się u siebie w domu ${ }^{32}$.

Zdaniem Zygmunta Gostkowskiego, deklaracja „Lodzer Zeitung” była świadomym wybiegiem redakcji tego narodowego pisma, które miało postawić w niezręcznej sytuacji jej polskich adwersarzy ${ }^{33}$. Być może tak

31 P. Samuś, Eódź - mata ojczyzna Polaków, Niemców, Żydów, [w:] Polacy, Niemcy, Żydzi w Łodzi w XIX-XX w.: Sąsiedzi dalecy i bliscy, Łódź 1997, s. 19; W. Kessler, Rola Niemców w Łodzi, [w:] Niemcy w dziejach Łodzi do 1945 roku, red. A. K. Kuczyński, B. Ratecka, Łódź 2001, s. 20.

32 Cyt. za: Z. Gostkowski, „Dziennik..., s. 154.

33 Ibidem. 
w istocie było, trudno jednak oprzeć się wrażeniu, że ów wiernopoddańczy manifest, który „Dziennik Łódzki” skomentował jako kuriozum, musiał wzbudzać zażenowanie również u sporej części łodzian pochodzenia niemieckiego. Z punktu widzenia władz zaborczych był to natomiast niemalże „tekst sponsorowany”, idealnie wpisujący się w realizowaną przez nie na terenie Łodzi politykę $e^{34}$.

Druga $\mathrm{z}$ wymagających sprostowania opinii, sformułowana przez Z. Gostkowskiego, wiąże proniemieckie nastawienie władz z istniejącymi w mieście podziałami klasowymi ${ }^{35}$. Rzeczywiście, mając zapewne w pamięci rok 1892, gdy zbiegły się one, tworząc niebezpieczną dla władz mieszankę, K. Miller połączył obie te kwestie w swoim raporcie z 1897 roku. Należy jednak podkreślić, że ochrona interesów przemysłowców przed żądaniami socjalnymi robotników była w Rosji stosowana przez władze niezależnie od tego, czy podziały klasowe szły - tak jak w Łodzi - w parze z narodowościowymi. Sam K. Miller, decydując się w 1892 roku na wprowadzenie egzaminów językowych dla kadry technicznej fabryk, pokazał, że spokój społeczny jest dla niego o wiele ważniejszy od interesów łódzkiej burżuazji niemieckiego pochodzenia. Nie bez znaczenia wydaje się też fakt, że gubernator znany był z osobistego germanofilstwa ${ }^{36}$.

Jak zauważył Piotr Szreter, autor artykułu o strategii warszawskiej cenzury przed 1905 rokiem:

jednym z najważniejszych zadań urzędów kontroli było podtrzymywanie za pomocą strategii cenzurowania istniejących podziałów społecznych. Starano się wytworzyć rozmaite dystanse komunikacyjne ${ }^{37}$.

${ }^{34}$ Zdecydowanie lojalistyczne nastawienie „Lodzer Zeitung”, będące podstawą zamknięcia tej gazety przez niemieckie władze okupacyjne w 1915 r., nie było cechą charakterystyczną prasy niemieckiej wydawanej w Łodzi. Jej konkurentki - „Lodzer Tageblatt” a potem „Neue Lodzer Zeitung” - starały się raczej łączyć lojalizm z propolskością. M. Kucner, Prasa..., s. 214.

35 Ibidem, s. 64-65.

36 J. Chańko, Gazeta „Rozwój”..., cz. 2, s. 263.

37 P. Szreter, Cenzura..., s. 257. 
W moim przekonaniu na terenie Łodzi, największego skupiska robotników w Królestwie Polskim, mieliśmy do czynienia z taką właśnie sytuacją: władze robiły wszystko, co w ich mocy, by nie dopuścić do przepływu idei między przedstawicielami inteligencji zaangażowanej w tworzenie miejscowej prasy i proletariatu. Wszelkie próby występowania przez prasę nie tyle w roli obserwatora spraw socjalnych, ile rzecznika interesów robotników, były dla władz nie do zaakceptowania, zagrażały bowiem zastanemu porządkowi społecznemu.

Uwarunkowania te stały się wyraźniejsze po 1897 roku, kiedy to wydawane w Łodzi gazety niemieckie, cenzurowane dotąd przez lokalne służby policyjne, wraz z ich polskimi odpowiednikami przeszły pod kontrolę samodzielnego urzędu cenzorskiego utworzonego wówczas w mieście i podległego bezpośrednio Głównemu Zarządowi do Spraw Druku w Petersburgu. Polityka kadrowa, którą stosowano do obsadzania tego stanowiska, zdaje się sugerować, że łódzka placówka była ważnym miejscem w systemie carskiej cenzury. Pierwszy cenzor łódzki, Piotr Piotrowicz Isajewicz, skierowany tu z Petersburga, choć nie sprawdził się na tym stanowisku a zarówno K. Miller, jak i urzędnicy WKC zarzucali mu zbytni liberalizm, musiał w oczach swych przełożonych uchodzić za osobę kompetentną, ponieważ po wymuszonym w zasadzie przez A. Imeretyńskiego odwołaniu z Łodzi objął funkcję jednego z cenzorów sztuk teatralnych w stolicy Imperium. Być może skierowanie do Łodzi było przejawem chwilowej tylko niełaski tego urzędnika, być może jednak - co wydaje się bardziej prawdopodobne - administracja Królestwa nie do końca rozumiała zadania, jakie postawiono mu w Petersburgu. Dla następcy P. Isajewicza, Iłłariona Andriejewicza Gabły, przeniesienie z WKC na samodzielne stanowisko w Łodzi oznaczało niewątpliwy awans. Często komentowaną w literaturze wątpliwość Petersburga, czy I. Gabła, nie posiadający dyplomu żadnego z uniwersytetów cesarstwa a jedynie polskiego uniwersytetu we Lwowie, podoła powierzonemu zadaniu, również świadczy o sporej ostrożności, z jaką typowano kandydatów na stanowisko cenzora w Łodzi. Ze środowiska petersburskiej cenzury, zdaniem Janiny Jaworskiej, wywodził się również następca I. Gabły, Anton Aleksandrowicz Paskal, z jednej strony bardzo skrupulatny, z drugiej nie stroniący od alkoholu i skompromitowany w 1905 roku związkami rodzinnymi z jednym z rewolucjonistów. Dopiero 
ostatni cenzor łódzki, a ściślej, według nowej nomenklatury - inspektor do spraw druku, pracujący od początku 1906 roku Wasilij Aleksandrowicz Pietrow, prezentujący zresztą dość intrygujący typ osobowości ${ }^{38}$, był byłym nauczycielem z Kalisza. Działał zresztą już w zupełnie odmiennych warunkach prawno-organizacyjnych niż jego poprzednicy ${ }^{39}$.

Istotnym novum $\mathrm{w}$ tym okresie było poddanie profesjonalnej cenzurze również gazet niemieckich ukazujących się w Łodzi. W tomach akt dotyczących cenzury z Kancelarii Gubernatora Piotrkowskiego znajduje się niemało raportów o artykułach zakwestionowanych na łamach „Lodzer Zeitung”, „Lodzer Tageblatt” czy „Neue Lodzer Zeitung”. Wiadomo też, że w okresie rewolucji zdarzały się konfiskaty nie tylko prasy polskiej, ale i niemieckiej ${ }^{40}$. Przypadki te wymagają oczywiście szczegółowego zbadania, zdają się jednak potwierdzać powyższe ustalenia o mniejszej niż dawniej przypuszczano opiece władz zaborczych nad środowiskiem niemieckim w Łodzi.

W stosunku do prasy polskiej ustanowienie odrębnego urzędu cenzorskiego niewiele zmieniło w zakresie polityki władz. Uderzający wydaje się zwłaszcza fakt, że ukazujący się od 1897 roku „Rozwój” Wiktora Czajewskiego, druga w historii Łodzi miejscowa gazeta polska - w odróżnieniu od „Dziennika”, prowadząca stałą walkę ze wszelkimi objawami niemczyzny w Łodzi - w okresie swego ukazywania się do 1914 roku w zasadzie uniknęła represji z tego właśnie powodu. Jak pisał Jan Chańko, autor opracowania poświęconego temu dziennikowi, aktywna antyniemiecka orientacja dominowała w publicystyce tego pisma w latach 1898-1904,

$38 \mathrm{~W}$. Pietrow nie wahał się oceniać cenzurowanych przez siebie pism za pomocą mało wyszukanego, obraźliwego słownictwa. I tak jeden z tytułów nazwał „poronionym przedsięwzięciem”, zaś dziennikarzy określał mianem „gadów prasowych” względnie „ludzi ograniczonych”. Pisząc o zawieszeniu „Kuriera Łódzkiego” stwierdził, że pismo to „zakończyło swą żałosną egzystencję". Jednocześnie wykazywał tendencję do wywyższania swojego stanowiska i zasług oraz krytyki innych organów władzy, z sądami na czele. Zob.: Prasa Królestwa Polskiego w opinii wtadz cenzury..., s. 27-28. Roczne raporty W. Pietrowa z lat 1906-1913 zob.: ibidem, s. 46-48, 50-56, 59-67, 73-76, 82-89, 97-103, 110-116, $123-127$.

39 Szczegółowe informacje o łódzkich cenzorach daje J. Jaworska, Cenzura..., s. 127, 130, 132-133, 143. Zob. też: Цензоры Российской Империи..., passim.

${ }^{40}$ Ibidem, s. 145 . 
a po chwilowym wyciszeniu w latach rewolucji 1905-1907, ponownie dała o sobie poznać po 1908 roku $^{41}$. Swoiste „przeczulenie” gazety na tym punkcie było z cała pewnością tolerowane przez władze.Nie oznacza to jednak, że stosunki „Rozwoju” z cenzurą i władzami przebiegały bezkonfliktowo, bez popadania w konflikty z kolejnymi cenzorami z powodu zamieszczania na swoich łamach artykułów zawierających - ich zdaniem - rozmaite aluzje społeczne, siejące „polski szowinizm” czy też wzbudzające „niezdrowe sensacje o podłożu antyrosyjskim" " ${ }^{2}$. Zwłaszcza ten ostatni przypadek był symptomatyczny, mówiący wiele o samej rosyjskiej cenzurze, dotyczył bowiem zamieszczonego w gazecie artykułu Zamordowanie gubernatora, informującego o zamachu na gubernatora odległej guberni rosyjskiej. Zdaniem cenzora A. Paskala tytuł taki miał sugerować mord na miejscowym gubernatorze piotrkowskim, przez co miał wzbudzać sensację ${ }^{43}$.

Charakterystyczną cechą działalności łódzkiej cenzury była jednak wielka ostrożność, z jaką kolejni cenzorzy podchodzili do przejawów podnoszenia kwestii socjalnych przez miejscowe dzienniki. Znamienne, że nawet W. Czajewski musiał tłumaczyć władzom, iż wydawany przez niego dziennik nie ma charakteru socjalnego. Swego rodzaju apogeum nastąpiło w 1900 roku, gdy I. Gabła zakwestionował umieszczony w „Rozwoju” artykuł Encyklika Ojca Świętego, zawierający popieranie jałmużny, upatrując w nim element „tak zwanego chrześcijańskiego socjalizmu”, czyli nauki społecznej Kościoła według Leona XIII ${ }^{44}$.

Kwestie socjalne stanowiły główną przyczynę problemów z władzami „Gońca Łódzkiego”, wydawanego od 1898 roku dziennika prezentującego liberalno-lewicowe skrzydło miejscowej prasy. Nie będę w tym miejscu szczegółowo omawiał wszystkich zatargów, jakie miało to pismo z cenzurą, zwłaszcza, że zostały one dokładnie przedstawione $\mathrm{w}$ artykule Janiny Jaworskiej ${ }^{45}$. Warto wskazać jednak na pewną logikę, która określała stosunek władz do tego dziennika, gdzie już w drugim numerze pisano, że

\footnotetext{
41 J. Chańko, Gazeta „Rozwój”..., cz. 2, s. 340.

${ }^{42}$ Ibidem, s. 263-266.

43 Ibidem, s. 266.

${ }^{44}$ J. Jaworska, Cenzura..., s. 131.

45 Eadem, „Goniec..., passim.
} 
zamiarem jego wydawców jest propagować „szlachetną, dodatnią i humanitarną myśl o dobrobycie mas ludowych" ${ }^{\prime 6}$.

Przesadą byłoby stwierdzenie, że władze nie tolerowały na łamach tego pisma jakichkolwiek artykułów dotyczących kwestii robotniczej. Przeciwnie, „Goniec” aktywnie się nią zajmował przez cały okres swego istnienia do 1906 roku; często na jego łamach podnoszono m.in. konieczność budowy tanich mieszkań dla ludzi pracy ${ }^{47}$. Interwencje cenzury i władz wywoływały te sytuacje, w których dopatrywały się one propagowania idei emancypacyjnych w środowisku robotniczym, a także występowania w roli rzecznika jego interesów. Znamienne, że cytowany już gubernator K. Miller nie krył oburzenia z powodu umieszczenia w jednym $\mathrm{z}$ artykułów wstępnych „Gońca” apelu o składanie redakcji donosów na majstrów wyzyskujących robotników ${ }^{48}$.

Obawa o wywoływanie emancypacyjnych ruchów w środowisku robotniczym zadecydowała zarówno o odrzuceniu w 1900 roku przez I. Gabłę dwóch opublikowanych już wcześniej w „Ekonomiście” artykułów Rynki pracy oraz Ubezpieczenia robotników w Europie Zachodniej. Zwłaszcza ten drugi artykut, który redakcja ostatecznie opublikowała mimo braku zatwierdzenia ze strony cenzora, narażając się na proces sądowy, poza informacjami o działalności związków zawodowych na Zachodzie zawierał także retorykę emancypacyjną. Pisano w nim mianowicie:

Nikt nie zaprzeczy, że wszystkie te kolosalne dobra, którymi tak zaszczytnie pyszni się nowożytna kultura nasza, są przede wszystkim dziełem pracy ludzkiej. Toteż, zda się, nie bardzo błądzą ci ekonomiści, którzy, jak np. p. Mill, istotną treść bogactwa społecznego upatrywać każą w sile roboczej, w zdolności do pracy członków danego społeczeństwa. Gdyby zniszczone zostały wszystkie płody cywilizacji, a pozostała jedynie praca, świat nie tylko, że nie zginąłby, lecz jak dotąd nadal by się rozwijał i postępował. Natomiast wyrugujcie energię czynno twórczą, ten sok żywot-

${ }^{46}$ H. Łubieński, Zaranie XX wieku, „Goniec Łódzki” z dn. 4 (16) lutego 1898, nr 2.

47 Zob.: K. Śmiechowski, Warunki mieszkaniowe robotników na tamach „Gońca Łódzkiego” (1898-1906), „Studia z Historii Społeczno-Gospodarczej XIX-XX wieku” 2012, t. 10, s. 105-120.

${ }^{48}$ APE, KGP, 1129; J. Jaworska, Cenzura..., s. 128. 
ny, nawet z najbogatszego, najdalej w ewolucji posuniętego społeczeństwa, a ono zmarnieje i z pewnością prędzej czy później żyć przestanie ${ }^{49}$.

Uzasadniając swój sprzeciw wobec publikacji tego, opublikowanego już przecież w poważnym czasopiśmie fachowym, artykułu, cenzor I. Gabła raz jeszcze dał wyraz jednej z zasad funkcjonowania cenzury w Królestwie, stwierdzając, że treści te nie powinny ujrzeć światła dziennego „z powodu specyficznych warunków panujących w mieście" 50 .

Oceniając politykę władz carskich wobec prasy polskiej w Łodzi do rewolucji 1905 roku, należy stwierdzić, że prowadzono ją nie bez sukcesów. Udawało się podtrzymywać różnice pomiędzy poszczególnymi grupami narodowościowymi zamieszkującymi miasto oraz izolować środowiska inteligenckie od klasy robotniczej. Ów drugi aspekt polityki władz okazał się na tyle skuteczny, że wydarzenia 1905 roku, polegające na wyemancypowaniu się całych mas robotników, zszokowały wręcz publicystów „Gońca” przekonanych, iż przemiany te powinny dokonywać się stopniowo, pod kierunkiem inteligencji ${ }^{51}$.

Nie ma potrzeby, by przypominać w tym miejscu cały szereg zmian, które spotkały prasę polską po 30 października 1905 roku $^{52}$ Okres porewolucyjny, z jednej strony oznaczający pewne polepszenie sytuacji wydawców i redakcji w wyniku znacznego ułatwienia uzyskiwania koncesji oraz zastąpienia uciążliwego systemu cenzury prewencyjnej represyjną; z drugiej, przynoszący bolesne represje w postaci zamykania kolejnych tytułów i procesów sądowych, był momentem przełomowym z jeszcze innego powodu. Umożliwił on mianowicie ujawnienie w całej rozciągłości podziałów ideologicznych i politycznych, występujących dotąd w formie częściowo utajonej pomiędzy poszczególnymi tytułami.

49 Ubezpieczenia robotników w Europie Zachodniej, „Goniec Łódzki” z dn. 15 (28) sierpnia 1900, nr 196.

50 APE, KGP, 1238, k. 41. Por.: J. Jaworska, „Goniec..., s. 373-374.

${ }^{51}$ H. Weberski, Sen i przebudzenie, „Goniec Łódzki” z dn. (01) 14 marca 1905, nr 67.

52 Zob.: Z. Kmiecik, Prasa polska $w$ rewolucji 1905-1907, Warszawa 1980, s. 11-42; M. Tobera, Cenzura prasy w Cesarstwie Rosyjskim na przetomie XIX i XX wieku, [w:] Piśmiennictwo..., s. 195-223; H. Bałabuch, Nie tylko..., s. 79. 
Prasa legalna zaczęła spełniać funkcję nie tylko informatora, ale również wpływowego ośrodka kształtującego poglądy i opinie współczesnego społeczeństwa ${ }^{53}$.

$\mathrm{Na}$ gruncie łódzkim oznaczał on opowiedzenie się prasy polskiej „Rozwoju” i „Gońca Łódzkiego” oraz jego następców - po dwóch stronach barykady politycznej, co $\mathrm{w}$ decydującym stopniu musiało determinować stosunek władz do tych dzienników.

Warto zaznaczyć, że nowe uwarunkowania utrudniły władzom dalsze prowadzenie polityki izolacji. Konfiskaty, które stały się teraz głównym środkiem $\mathrm{w}$ walce $\mathrm{z}$ wolnością słowa, nie osiągały $\mathrm{w}$ pełni zamierzonego skutku: zakazane treści trafiały w obieg nim cenzura zdołała podjąć odpowiednie kroki. Dotychczasowe ambicje inspirowania prasy do działań w określonym kierunku musiała zastąpić funkcja czysto represyjna, wtórna wobec wcześniejszej praktyki. Ostrze represji nie zostało skierowane w równym stopniu w dwie zwalczające się orientacje. Okres lat 1905-1914 łagodniej udało się przetrwać „Rozwojowi”, który stał się w tym czasie organem wyraźnie sympatyzującym z Narodową Demokracją. Wybór ten, wynikający z dotychczasowych tradycji i wyborów ideowych gazety, sprawił, że „Rozwój”, będąc formalnie pismem komercyjnym, zaczął propagować na swych łamach treści zbliżone do oficjalnych organów tego stronnictwa ${ }^{54}$. Przejawiało się to z jednej strony w poddawaniu ostrej krytyce stronnictw socjalistycznych oraz obwinianiu ich o wzbudzanie niepokojów rewolucyjnych, z drugiej zaś w propagowaniu możliwości legalnego włączenia się w działalność polityczną pojawiających się w wyniku liberalizacji życia publicznego, z których Narodowa Demokracja korzystała wówczas na dużą skalę ${ }^{55}$. Ujemną stroną działalności gazety, stale prowadzącej akcję krzewienia polskości w Łodzi, był nasilający się antysemityzm, który nie spotykał się z należytą reakcją ze strony cenzury ${ }^{56}$. Pismo nie uniknęło zawieszenia ani w końcowym okresie rewolucji, ani w kolejnych latach. Ich powody były przeróżne, mieściły się jednak w kanonie przyczyn, w wyniku których

53 Z. Kmiecik, Prasa..., s. 261.

${ }^{54} \mathrm{O}$ prasie narodowej demokracji w okresie rewolucji zob.: ibidem, s. 120-149.

55 J. Chańko, cz. 2, s. 320, 322-323.

56 Ibidem, s. 347-350. 
w nowym systemie prasowym dochodziło do represjonowania prasy i jej twórców. Obejmowały one opublikowanie apelu Henryka Sienkiewicza o składanie datków na rzecz Polskiej Macierzy Szkolnej z okazji święta Konstytucji 3 Maja, streszczenie artykułu z rosyjskiej prasy o reformach konstytucyjnych w Rosji, adresu grupy łódzkich Niemców o rozdzielenie szkół elementarnych w Królestwie na niemieckie i polskie; wreszcie informacji o interpelacji jednego z posłów do Dumy w sprawie nadużyć władz prowincjonalnych ${ }^{57}$. Wiktor Czajewski nie uniknął również krótkiej kary więzienia za rzekomą obrazę armii zawartą w jednym z artykułów ${ }^{58}$. Całość represji pod adresem gazety uzupełniały liczne grzywny.

Represje spadające na redakcję „Rozwoju” nie mogły się jednak równać z tymi, które stały się udziałem "Gońca Łódzkiego”, „Kuriera Łódzkiego” i „Nowego Kuriera Łódzkiego”59. Jak trafnie zauważył Zenon Kmiecik:

równocześnie z ogłoszeniem nowych przepisów prasowych [w grudniu 1905 - K. Ś.] wzmogły się represje wobec pism solidaryzujących się z rewolucją i w ogóle ruchem wolnościowym ${ }^{60}$.

„Goniec”, co warto podkreślić, również podchodził sceptycznie do walk rewolucyjnych, promując raczej legalne sposoby rozwiązania kwestii społecznych i politycznych. Ich wdrożenie wymagałoby jednak znacznie gruntowniejszej przebudowy życia politycznego w Rosji niż taka, na którą gotowe były zgodzić się zarówno rosyjskie elity państwowe, jak i spora część ruchów politycznych o obliczu konserwatywnym. Na łamach dziennika pojawiały się licznie odważne artykuły o tematyce politycznej ${ }^{61}$, co sprawiło, że na początku 1906 roku władze zawiesiły jego wydawanie. Ostatecznie, wyrokiem z 1907 roku piotrkowski sąd postanowił o likwidacji pisma „raz

57 Ibidem, s. 268-271.

58 Ibidem, s. 271.

59 Wiosną i jesienią 1906 r. nie było miesiąca, w którym cenzura nie kwestionowałaby artykułów zamieszczanych na łamach „Gońca”, a potem „Kuriera”. AP£, KGP, 1572-1573. Nieustający konflikt między inspektorem W. Pietrowem a „Kurierem” i „Nowym Kurierem Łódzkim” trwał również w 1911, 1912 i 1913 r.: APŁ, KGP, 1775, 1814, 1845.

60 Z. Kmiecik, Prasa..., s. 29.

${ }^{61} \mathrm{~Np}$. H. Fraenkel, Dziesięć dni na Pawiaku, „Goniec Łódzki” z dn. 15 grudnia 1905, nr 312; cz. II, „Goniec Łódzki” z dn. 20 grudnia 1905, nr 320. 
na zawsze” oraz skazaniu jego redaktora Jana Żółtowskiego na karę trzech miesięcy więzienia ${ }^{62}$.

Liberalno-lewicowe skrzydło łódzkiej prasy, podobnie jak wiele innych tytułów wydawanych w Królestwie, uratował jednak swoisty paradoks systemu prasowego obowiązującego po rewolucji 1905 roku. Okres ten, charakteryzujący się olbrzymią liczbą kar administracyjnych i wyroków sądowych nakładanych na dziennikarzy i wydawców, stworzył też zupełnie nowe ramy dla uzyskiwania pozwoleń na wydawanie pionierskich czasopism. W łódzkich realiach potwierdziła się powszechnie obowiązująca wówczas zasada mówiąca, że „zamknięte pisma redaktorzy szybko wydawali pod nowymi tytułami”63. „Gońca” zastąpił „Kurier Łódzki”, dziennik kontynuujący linię swego poprzednika i podobnie jak on pozostający w ciągłym zatargu z władzami. Tytuł ten, nazwany przez Zenona Kmiecika „najpoważniejszym pismem regionalnym w Królestwie”, mimo że już w 1907 roku otarł się o likwidację za swoją postawę w okresie tzw. lokautu łódzkiego ${ }^{64}$, przetrwał jednak do 1911 roku. W przygotowanej dla gubernatora „Charakterystyce prasy regionalnej za rok 1911” cenzor W. Pietrow nie miał wątpliwości o szkodliwości „Kuriera”, nazywając go „postępowym organem o niewątpliwie socjalistycznym charakterze” ${ }^{65}$. Po takiej „pośmiertnej” ocenie cenzora, przypominającej wyrok, nie dziwi to, że dziennik o takim nastawieniu analogicznie, jak przed pięciu laty - musiał został zlikwidowany; odrodził się jednak pod postacią „Nowego Kuriera Łódzkiego”, wydawanego już do końca interesującego nas okresu, choć stale narażającego się na konfiskaty i zawieszenia, choćby poprzez publikowanie artykułów krytykujących

${ }^{62}$ J. Jaworska, „Goniec..., s. 388-389.

${ }^{63}$ Z. Kmiecik, Prasa..., s. 33.

${ }^{64}$ W. Kaszubina, Notatki..., s. 173; J.Jaworska, „Goniec..., s. 146. Siedmiomiesięcznej kary więzienia nie uniknął wówczas redaktor odpowiedzialny gazety Wiktor Monsiorski, który odnalazł się później w roli redaktora „Głosu Zagłębia”. Wyrazem odwagi ze strony redakcji było opublikowanie dowcipnego, prowokacyjnego listu, który były redaktor wysłał zza krat do czytelników: Kronika miejscowa, „Kurier Łódzki” z dn. 19 sierpnia 1908, nr 375.

${ }^{65}$ Charakterystyka prasy regionalnej za rok 1911, APŁ, KGP, 1814, k. 165. 
istniejący w Cesarstwie ład prawny i domagających się dalszych reform ${ }^{66}$. W lekturze raportów inspektora W. Pietrowa z lat 1912-1913 uderzające wydaje się podkreślanie lojalności „Rozwoju” przy jednoczesnym poszukiwaniu pretekstów do nakładania kar na redakcję „Nowego Kuriera”67.

Skala represji, jakimi obejmowano wspomniane dzienniki, w porównaniu z "Rozwojem” wskazuje na nasilającą się z biegiem lat asymetrię w traktowaniu przez władze poszczególnych tytułów prasy łódzkiej po 1905 roku, w zależności od ich zróżnicowania ideowego. Mimo nowych uwarunkowań, utrudniających prowadzenie polityki „inspirowania” prasy do określonych zachowań, władze starały się kontynuować na terenie Łodzi działania oparte na wypracowanych przez wiele lat zasadach. Polegały one - przypomnijmy - na dążeniu do zachowania pozycji rozgrywającego w skomplikowanych stosunkach narodowościowych miasta oraz jednoczesnego izolowania od siebie poszczególnych warstw społeczeństwa, mającego służyć utrzymywaniu porządku publicznego i gaszeniu w zarodku, przynajmniej dopóki było to możliwe, wszelkich napięć społecznych o charakterze socjalnym. Polityka ta, mimo wymiernych sukcesów, nie przeszkodziła jednak łódzkiej prasie w zachowaniu „wewnętrznej suwerenności” ${ }^{68}$. W ten sposób dzieje relacji łódzkiej prasy z władzami zaborczymi i cenzurą miały z jednej strony charakter typowy dla dziejów prasy Królestwa Polskiego przełomu XIX i XX wieku, z drugiej zaś zachowywały cechy oryginalne, wynikające $\mathrm{z}$ miejscowych uwarunkowań, tak często podkreślanych przez poszczególnych przedstawicieli władz. Cechy te - powtórzmy - obejmowały dość daleko idące przyzwolenie cenzury i władz na podgrzewanie antagonizmów narodowościowych - polsko-niemieckiego, a potem również polsko-żydowskiego - w tym wieloetnicznym i przemysłowym mieście oraz

${ }^{66}$ Np. w kwietniu 1913 r. „Nowy Kurier” ostro skrytykował Radę Państwa za odrzucenie projektu ustawy o odpowiedzialności cywilnej urzędników, domagając się wręcz rozwiązania izby wyższej rosyjskiego parlamentu: Pereat iustitia...!', „Nowy Kurier Łódzki” z dn. 19 kwietnia 1913, nr 90. Za artykuł ten gazetę skonfiskowano oraz wszczęto przeciw jej redakcji śledztwo: APE, KGP, 1845, k. 38.

${ }^{67}$ Charakterystyka druków periodycznych [w Łodzi] w 1912 roku, [w:] Prasa Królestwa Polskiego w opinii wtadz cenzury..., s. 111; Charakterystyka [tódzkich] druków periodycznych w 1913 roku, [w:] ibidem, s. 123.

${ }^{68}$ M. Tobera, Cenzura..., s. 67. 
szczególną skrupulatność w kontrolowaniu treści społecznych pojawiających się na łamach prasy.

\section{Strategies of tsarist authorities for the daily press in Łódź before 1914}

(SUMmARY)

Łódź is an example of place where tsarist authorities and censorship had a significant impact on the existence of daily newspapers. Especially Polish press, represented by titles like "Dziennik Łódzki", "Rozwój”, "Goniec Łódzki”, "Kurier Łódzki" and others, were subjected to repressions. The article describes authorities' strategies, which was used to control social and political activity of the newspapers. First of them was a strategy of isolation of particular ethnic groups living in the city. Russian administration considered the process of polonization of the city, dominated traditionally by Germans, as dangerous. In their point of view, conflicts between Poles, Germans and Jews strengthened the Russian rule in that part of partitioned Poland. The second strategy was an isolation of social classes, especially intelligentsia and workers. The authorities were afraid of strikes and workers' riots as a potential causes of a revolution. Elimination of far-reaching social ideas from the newspapers was a important task of the Łódź's censor, whose office was established in 1897. It should be considered, that the authorities was succeed in realization of its press policy in Łódź. After the Revolution of 1905, when a political and legal order in Russia was changed, the Polish daily press published in Łódź was still a victim of repressions, including closures of titles, trials and imprisonment for journalists and editors. As a result, the progressive, social sensitive press represented by "Goniec Łódzki", "Kurier Łódzki" and "Nowy Kurier Łódzki" was treated much harsher than nationalistic and anti-Semitic "Rozwój”.

Kamil Śmiechowski

Instytut Historii, Uniwersytet Łódzki e-mail: ksmiechowski@gazeta.pl 